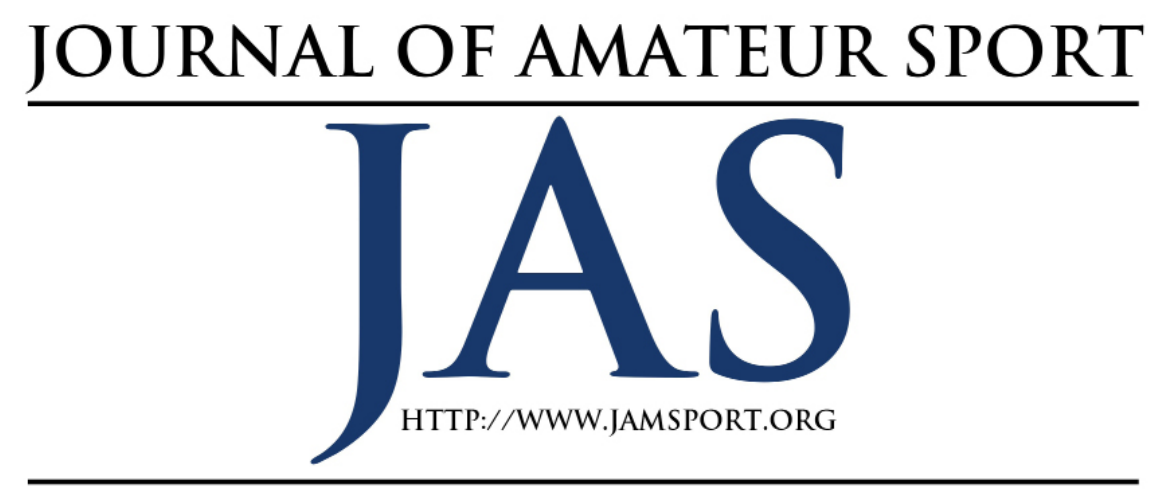

\title{
The Changing Landscape of the Team Uniform Sales Market
}

\author{
Matthew Y.H. Smith ${ }^{1}$ \\ Timothy Kellison ${ }^{1}$
}

\author{
Brandon Pottebaum ${ }^{1}$ \\ Beth A. Cianfrone ${ }^{1}$
}

${ }^{1}$ Georgia State University

\begin{abstract}
The amateur team uniform sales market, long run through small, local shops and sales representatives, is undergoing profound change. The rise of customization and ecommerce may be leading long-time retailers to weigh the benefits of adopting new tactics versus maintaining traditional sales strategies. To gain insight on the team uniform sales market, semi-structured interviews were conducted with six professionals with histories working in the sporting apparel industry. In sum, the participants had more than 40 years of experience. Based on the interviews, several themes emerged that capture the amateur team uniform sales market, including the current market conditions, changes in the market landscape over the past decade, and forecasts for the future of the uniform sales market. The results of the study indicate the amateur team uniform sales industry is rapidly changing, and that the large number of independent dealers and the rise of consolidation are leading to a more crowded and competitive marketplace.
\end{abstract}

ccording to the Aspen Institute,
in 2016, more than 36\% of
children ages $6-12$ played team sports on a regular basis (and were considered "core" users because they typically competed a number of times a year in a level of organized play; Aspen Institute,
2017). Additionally, the National Federation of State High School Associations (NFHS) estimates nearly 8 million students participate in interscholastic sports among its member institutions (National Federation of State High School Associations, 2018). From 2016 to 2017, there 
was almost a 100,000 -student jump in the number of NFHS participants, largely in part to female sports participants, with female participation numbers increasing 75,000 alone in the last census. This past year's "High School Athletics Participation Survey" indicated there were more than 60 different sports offered throughout high schools nationwide. In the nearly 50 years since the NFHS survey first began, participation has nearly doubled, from about 4 million in 1971 to almost 8 million participants today.

With this increase in participation has come the growth of traditional sports sectors and the emergence of new ones (e.g., Scheerder, Vos, \& Taks, 2011). One of the larger sub-industries within the sports industry is that of athletic apparel. In this space, there are the titans of the industry like Nike, Adidas, Under Armour, and Lululemon, all of which are multi-billion-dollar companies (Cheng, 2018). The athletic apparel market is also experiencing rapid growth as athleisure wear rises in popularity. Athleisure characterizes style preferences that encourage comfort over name-brand recognition. Within the sub-industry of sporting apparel and athleisure wear, there is still yet a more-specific market: one in which the focus is on team uniform sales.

Trade groups like the Sports and Fitness Industry Association (SFIA) and Sporting Goods and Manufacturers Association can give some insight into the size and scope of the sports apparel market. For instance, a report published by the SFIA (2015) found performance apparel surpassed $\$ 1.5$ billion in 2014. A more recent analysis conducted by IBISWorld (2017) detailed the market for costume and team uniform manufacturing. They estimated the market to be worth roughly $\$ 1$ billion, and is composed of more than 10,000 employees working across nearly 2,400 businesses. These trends are predicted to continue as athleisure wear becomes more and more acceptable in Western societies (Craik, in press).

While these sources provide important perspectives on market size and growth, there is little information about the strategies and industry trends that have impacted vendors and salespersons. It is common practice for organized sports teams to require matching uniforms of some sort, and this rule applies at every level of sport engagement ranging from the little leagues to professional sport. Even team sports in which participants may compete individually, such as golf or swimming, will often have a need for team uniforms in some capacity. For example, a collegiate tennis team may be required to wear a team uniform despite the fact they are often competing as individuals. In another case, a youth swimming club may don matching "warmup" apparel over their swimsuits.

Historically, the model for team uniform sales and distribution has been static. Apparel brands like Nike and Adidas would sell blank apparel to team dealers with which they partnered. As intermediaries, these team dealers would serve as the contact responsible for selling the gear directly to teams. Team dealers often worked with several different brands and 
had the right to sell whatever they were able to whomever would purchase it. However, in the past decade, this structure has undergone a radical shift.

Surprisingly, despite the team uniform market being a multi-million-dollar business, there have been few studies that have explored the industry, and there is little academic literature on this particular sector. In light of this lack of research, the purpose of this study is to provide insight on the amateur team uniform sales market. Specifically, by consulting with industry professionals with a wide range of responsibilities and expertise in the market, we focus on current market conditions, changes in the market landscape over the past decade, and forecasts for the future of the uniform sales market. To provide a foundation on which this study is based, we review the extant literature on team uniforms and performance apparel below.

\section{Literature Review}

While team uniforms are hardly a new product, information tracking in this area has been scarce. In the academic literature, research on team uniforms and uniform manufacturers has largely centered on brand personality, brand equity, and sponsorship (Bouchet, Doellman, Troilo, \& Walkup, 2017; Scola \& Gordon, 2018; Su \& Tong, 2015; Wear, Heere, \& Clopton, 2016); the institutional strategies of multinational corporations (Baumann-Pauly, Scherer, \& Palazzo, 2016); and psychological effects associated with uniform color selection (Attrill, Gresty,
Hill, \& Barton, 2008; Spencer, 2017). In addition, trade-related publications have focused on the changing marketplace of varsity award jackets (Pallerino, 2009) and advances in uniform features and technology (Delgado, 2012).

One line of interest in trade publications and academic research has been on defining the individuals charged with purchasing team-related products (e.g., performance apparel, protective equipment, sporting goods) and identifying the most effective strategies for maximizing sales. Thomson (2009) approached this topic from a consumer perspective, detailing several key issues in the sporting goods sector, including striking a balance between price and value, deciding on brand names, considering shipping costs, and establishing relationships with sporting goods companies. He noted that even throughout high school athletics, coaches and teachers are primarily the individuals who decide on what equipment and apparel to purchase. Some of Thomson's focus is on the differences between big-name conglomerates and small- and mid-sized companies. In particular, he explained the strategies smaller companies adopt to keep up with their larger competitors:

...Because small or "no name" companies don't have the brand name recognition that drives sales, they have to rely on the time-honored technique of being dependable. They must have quality items and have them in stock, ready to ship within a day or two. (p. 21) 
In general, Thomson advised consumers (i.e., in this case, coaches and teachers) to consider independent retailers or smaller sporting goods dealers because they "are generally easier to work with" and "offers the chance to buy product at a discount" (p. 21). For Thomson, this preference is based in large part on the availability of local dealers and vendors for personal attention, dependability, the opportunity to sample products in person, and overall familiarity.

Of course, the changing nature of the industry and rise of online marketplaces (i.e., ecommerce) have made it increasingly difficult for low-volume and local vendors to maintain competitiveness with larger retailers. This challenge was illustrated in the ESPN 30 for 30 Short documentary "Friedman's Shoes" (Lee, 2016), which chronicled the struggle of a once-bustling shoe store in Atlanta popular among NBA and NFL players as it struggled to stay afloat following the explosion of online retail. Ultimately, Friedman's launched its own online store to keep the business viable.

In the case of Friedman's and other brick-and-mortar retailers, the rise of ecommerce has forced business owners to consider pivoting to online markets to maintain competitiveness with new online companies. Despite the popularity of online shopping, previous research suggests many consumers may still prefer the in-person experience when it comes to some products. For instance, in Ko et al. (2012), the researchers attempted to segment consumers in the sportswear industry and found that although the internet was a popular purchase place, specialty stores were still the most common place to purchase sportswear across all four lifestyle segments. While businesses may implement new marketing and sales strategies on an individual basis, previous research has shown that industrywide trends may also emerge when it comes to innovation adoption. Additionally, consumers play an important role in the innovation process. In Desbordes's (2002) analysis of sporting equipment manufacturers' willingness to change or adapt to consumer needs, he argued:

...To be accepted, sports products need to be technologically efficient, well designed and proposed at a reasonable market price. ... The sports equipment industry is more similar to the automobile industry where both dimensions (technology and marketing) have an equal importance. (p. 486)

Similar concerns may exist among current team uniform suppliers facing the reality of a growing presence from online competitors. As teams and leagues are afforded more options, including purchasing products using an online platform, some retailers may be reluctant to follow suit.

Additional literature, while not directly addressing the uniform sales market, is nevertheless relevant to the sales market structure. In one example, Rouziès et al. (2005) found that marketing and sales were intricately connected in a wide range of product categories, and their proper integration could produce pos- 
itive business outcomes. In the realm of team uniform sales, brands like Nike and Adidas often function as the primary marketing company, while dealers function as the brands' sales force. In this example, it is important for brands and dealers to have consistent messaging regarding their products, as a unified message will likely produce increased revenues. However, to maximize integration between sales and marketing, apparel brands may start to cut out the dealers in an effort to minimize inefficiency in their marketing and sales divisions and increase overall profits. This potential threat to dealers will be discussed in further detail in a later section.

An additional line of research has focused on the factors that contribute to a consumer's preference for specific styles and brands. Mays and Bass (2016) apply fashion theory to explain why consumers may purchase one brand's product over that of a competing brand, even if the competitor's product is similar in quality and lower in cost:

A workout shirt made by Nike and a similar shirt made by Russell [Athletic] are functionally equivalent without previous knowledge of the two brands. However, the symbolic meaning within sports culture of Nike compared to Russell encourages athletes to prefer one brand over another. (p. 384)

Furthermore, they observed how consumers' individual preferences have launched new sales strategies that allow consumers to personalize footwear and apparel by modifying colors and adding embroidery. The concepts of individualization and customization, particularly when it comes to high-volume orders with multiple products, can be more easily facilitated through an ecommerce platform.

As consumer demand for customization and a large offering of choices has grown, athletic apparel brands must stay abreast of the latest trends and product developments to stay competitive. Additionally, they must have the personnel and manufacturing capacity to quickly alter existing products and introduce new ones, whether those changes are occurring in traditional or in rapidly emerging product lines. An example of the latter case is the rise in activewear, or athleisure, which has not only required the manufacturing of new products, but also inspired new lines of market research (O'Sullivan, Hanlon, Spaaij, \& Westerbeek, 2017; Wray \& Hodges, 2008).

A review of literature on the team uniform market indicates that, in general, the topic has received little scholarly interest. While research originating outside the sport management literature may provide some superficial application, to the authors' knowledge, there have not been any attempts to explore the amateur team uniform sales market. Such research is particularly timely, as the rise of customization and ecommerce may be leading long-time retailers to weigh the benefits of adopting new tactics versus maintaining traditional sales strategies. In the next section, we outline our approach to investigating the current practices and 
market forecasts of professionals in the amateur team uniform sector.

\section{Method}

To gain insight on the team uniform sales market, semi-structured interviews were conducted with six professionals with histories working in the sporting apparel industry. Institutional Review Board approval was obtained, and participants were identified because of their roles as upper-level managers of organizations involved in the manufacturing or delivery (or both) of sports uniforms. In sum, the participants had more than 40 years of experience. Three participants owned their companies, two others were C-level executives, and one participant was a sales representative.

Interview questions centered around three key themes. First, participants were asked to comment on current market conditions. Included in this discussion was an assessment of current opportunities and threats. Second, participants described changes in the market landscape over the past decade. Third, participants provided forecasts for the future of the uniform sales market. These forecasts were primed by questions related to particular technological advancements that may be occurring and company changes each participant would like to implement if possible. A list of the primary interview questions is provided in Table 1.

Interviews were conducted either face-to-face or over the phone. Face-toface interviews occurred in the participants' offices. All interviews were completed in 20-40 minutes. The empirical material was analyzed by a single coder; while the coder consulted with his co-au-

Table 1

\section{Interview Questions}

1. How would you currently describe the market for team uniforms?

2. What have been the biggest changes within the team uniform market in the last five years?

3. In what ways has the rise in social media changed the ways you do business?

4. Where do you think the future of the team uniform sales market is headed?

5. Are there any particular technological advancements that you feel may change the industry?

6. If you could change one thing about how your company competes in the market, what would it be?

thors, the coding process was completed independently, a common practice in content analysis (Krippendorff, 2004). Several techniques were used to provide evidence of trustworthiness, including audiotaping, verbatim transcription, and member checking during the interviews and after the completion of the manuscript. To maintain participant confidentiality, all participants were assigned randomized pronouns and pseudonyms. For a list of the participants, including their titles, company types, job roles, and years of industry experience, refer to Table 2 . 
Table 2

Summary of Participants

\begin{tabular}{l|l|l|l|l}
$\begin{array}{l}\text { Name } \\
\text { (pseudonym) }\end{array}$ & Title & Company Type & $\begin{array}{l}\text { Role in } \\
\text { Industry }\end{array}$ & $\begin{array}{l}\text { Years in } \\
\text { industry }\end{array}$ \\
\hline Madeline & Founder and owner & Apparel brand (basketball) & Brand & 8 \\
\hline Felix & Chief operating officer & Apparel brand (basketball) & Brand & $4-5$ \\
\hline Abigail & President and owner & Apparel brand (ultimate) & Brand & 6 \\
\hline Henry & Manager and co-owner & $\begin{array}{l}\text { Apparel brand with retail } \\
\text { outlet }\end{array}$ & Dealer & 21 \\
\hline Caroline & Sales representative & Apparel dealer & Dealer & 2 \\
\hline George & Chief executive officer & Software developer & Ecommerce & $2-3$
\end{tabular}

\section{Results and Discussion}

From the three broad questions selected to drive inquiry, several themes emerged that capture the amateur team uniform sales market and offer some insight into where the industry is headed. These themes are discussed in detail in the following sections.

\section{Assessing the Current Sales Market}

To begin their analyses, participants were asked to describe the current market for team uniforms. When it came to the financial health of their businesses, all participants responded positively. Henry, the manager and co-owner of an apparel brand and 21-year industry veteran, simply described business as "good," while Caroline, currently in her second year as a sales representative for an apparel dealer, noted the market was strong and offered "good job security." These assessments come at a time when the industry is undergoing significant growth, as described by several professionals. For instance, Felix, the COO of a basketball apparel brand, characterized the market as "changing rapidly"; similarly, Abigail, who has been president and owner of an apparel brand for six years, explained the market was growing, particularly in the sport in which her company specializes, ultimate (frisbee). The current market landscape for team uniform sales could be described as robust, as all interviewees expressed belief that there were significant amounts of activity and concomitant demand. Despite these optimistic assessments, some interviewees offered hints that the growing market-while strong from a financial perspectivemeant the marketplace itself could be volatile. The "wild, wild west" is how George, the CEO of an ecommerce software developer, described the overall market. Finally, Madeline, the founder and owner of a basketball apparel brand with eight years of experience, pointed out the basketball-specific market was "underserved." 
George provided additional insight into the industry and defined the four major role players in the team uniform sales sector. First, the brands manufacture products, and although a handful of major athletic brands dominate the industry, there is no shortage of alternatives, particularly when it comes to the amateur uniform market:

There are no less than 1,500 other brands that folks aren't aware of. There are many, many brands. Truly, thousands of middle-tier brands—good, better, best. So pretty much if you're a Nike, Adidas, [or] Under Armour dealer, you're selling that.

In the event a team or organization is interested in additional products like practice gear or spirit wear ("the extra stuff"), the dealer "will fill those with alternative brands." As George explained, the majority of sales occur at the local level by the second role player, the local sports dealer. The dealer maintains an inventory of products and is responsible for taking the delivery of those brands and providing customization (e.g., stitching, sublimating). Third, network partners include firms like George's ecommerce company that "make [the selling] process easier to facilitate online sales to the direct customer." Those consumers represent the fourth and final role player.

\section{Reflecting on the Past to Prepare for the Future}

Some of the team uniform professionals' optimism for the industry is undoubtedly based on their companies' abilities to evolve as business practices have changed. When asked to identify trends over the past 5-10 years, several key themes emerged, including market consolidation, generational shifts, and growth in ecommerce platforms. Each of these themes are discussed in turn below.

Market consolidation. Market consolidation refers to a process in which many companies within an industry merge so there are fewer independent entities. This process often occurs via private equity firms that purchase promising companies within an industry, consolidate them, and then either look to resell the new company or keep it operating at a profit. As discussed previously, George estimated there are currently over 1,500 independent apparel brands, and it is unlikely that number will be sustainable in the long term. To explain the way in which market consolidation works, Madeline used the following analogy:

If you go back five, maybe 10-15 years, on Main Street, USA...you had same core business: Army/ Navy store, general store, women's fashion store, men's fashion store - that's kind of what you'd see on Main Street, and among those [there] usually was a team dealer who also served as screen printer and embroidered. What [consolidation firms have] done is they've acquired anyone who has a reasonably good size business, they've acquired all of them, and 
now they have an 800-person sales force that's effectively a national team dealer.

The emergence of this type of company is a relatively recent development, and it stands to threaten the long-term health of smaller, local shops.

When it came to discussions about market consolidation, one particular company was identified by four of the interviewees without prompting: BSN Sports. This company, which started in 1972 with its "founder selling tennis nets out of the trunk of his car" (BSN Sports, 2018), seeks to use its large online presence to be athletic teams' "one-stop shop" for apparel, footwear, and equipment. On its website, they offer to outfit almost any team playing any sport, and a consumer can go through them for every part of the purchasing and customization process. What makes BSN particularly threatening is that it can underprice its products to secure customers. As Felix argued, "What BSN is doing is buying customers. They don't care about local businesses; they care about [those businesses'] customers." He added: “They will basically be able to provide a cheaper price, or if not an equal price, and their acquisition costs will be significantly lower than...the little guy's. They're just trying to get access to those customers."

Felix also suggested that BSN Sports itself may one day be consolidated. That is, one of the major athletic apparel brands like Nike, Under Armour, or Adidas may decide that BSN Sports is the best channel for distributing their prod- ucts effectively and may decide to buy them and turn them into a part of their own supply chain network. For example, "Nike may decide to buy BSN because they're already their biggest customer, and if that's the easiest way to funnel all of [their] team business, then great. Maybe that becomes their play."

To Abigail, consolidation is not an immediate threat among companies whose core sport is ultimate. She noted that in the market for ultimate team uniforms, there had actually been an increase in brands over the last 7-8 years, though all have been low-quality, high-volume competitors, and the market did not appear to be consolidating. When she started, she said there were only five companies she was competing with, and now there are at least 10 major companies whose focus is ultimate apparel, some of whom are based abroad and are able to manufacture items at a lower cost. Still, although consolidation is not a common practice among ultimate-based companies, it has found its way even into the ultimate realm:

I've bumped into [apparel conglomerates like BSN Sports]. They like to go into a school and say, "We want to be your supplier for every sport. We'll throw a bunch of money at you to make that happen." I'm pretty lucky in that they don't have a clue about ultimate. They keep trying to push basketball and volleyball shorts onto ultimate players, and that's not what they want to wear. 
However, she fears one day "they'll figure it out" and become legitimate competitors in that space. Despite BSN being in business since 1972, interviewees indicated that many of the company's major changes have come in the last five years. BSN Sports represents what one consolidation model looks like: one company buying up any small, successful businesses and then integrating them into its business model in an attempt to become a one-stop shop.

Generational shifts. An inevitable change in the industry relates to demographics. Specifically, the generational shift in the team uniform sales market is occurring at two levels: the coaches making purchasing decisions and the team uniform dealers. In general, both groups are getting younger and showing more comfort using the internet and ecommerce platforms. Four of the interviewees mentioned generational shift as a current market factor. In regard to the change in the demand side of the business (i.e., from the coaches), younger coaches were characterized as being far more fluent in ecommerce and navigating the internet. In fact, these younger coaches are putting pressure on dealers to provide technologically advanced services. As Henry summarized,

The new generation does not want to talk to you at all. If you call, they are like, "Please email or text. We don't want to call or talk to anyone. We would rather just have the information available to us on the screen and then just go from there."

As preferences shift with the rise of a new generation of consumers, suppliers may have to consider the fact that the personalized, in-person sales approach common with previous generations is no longer the accepted standard.

Henry himself represents the generational shift in the other significant demographic, the team dealers. These dealers, many of whom operate out of small brick-and-mortar storefronts, are generally older men nearing the age of retirement. They have conducted their business in team uniform sales in one way for quite some time-via personal relationships with coaches and pen-andpaper orders - and they are not eager to entirely change their business model in the twilight of their careers. Henry represents the next generation of owner; he is part owner of a company along with his father, who started the business. His father is looking to become less involved, and Henry has increasing control of the company's day-to-day operations. He is aware of the generational shift occurring among his clientele and is planning ways to meet their new demands. In fact, when presented with the option of adding one resource to his current business model, he said it would be "ecommerce talent." This specialization, he argued, would include employees who were comfortable with social media as well as modern software that generates team uniform sales via online platforms. 
George concurred with the argument that sales teams needed to stay on top of technological developments in order to survive. He also credited his ecommerce platform with helping many older companies make the transition to online and mobile sales:

There's a generation of people, and most of our dealers are of the age, that ...started out as high school football coaches 20 years ago, so not a lot of them are technology savvy. But the end customer is now very technology savvy, so it's putting pressure back on the dealer to get with the technology to change how they do business. Very selfishly, [our business is] one of those catalysts of change.... Knowing that there's an easier way for parents, coaches, [and] athletic directors to have an online store cuts them out of it - and they don't want anything to do with it - and it simplifies the order process for them.

For companies whose staff simply lack the technological literacy to manage an online presence, a network partner may enable such companies to maintain a digital marketplace.

Of course, one of the mobile technologies changing the market is social media, which has seen a surge in popularity over the last decade. Two of the companies represented in this study expressed that they take their social media presence very seriously. Neither viewed social media as a significant sales channel, but interviewees contended it still held tremendous value as a marketing tool and as a way to engage with customers. According to Felix, social media also offers insightful tracking information, which makes it relatively easy to find customers who are likely to be interested in his products. The strengths, most interviewees argued, were that social media could provide a "branding exercise" (Madeline), "a marketing channel" (Abigail), "more exposure" (Henry), or "storefronts in social media" (m-commerce; George).

\section{Growth in ecommerce platforms.} As noted in the above section, changing demographics have necessitated the adoption of online sales platforms for most team uniform companies. The rise of ecommerce platforms was a consistent theme found throughout participants' testimonies. However, in addition to consumers' expectations that companies sell goods through an online marketplace, they may also look for other expectations often associated with online retailers. For example, George identified Amazon.com as the biggest demand driver: "There are multiple ways Amazon is [changing the market] besides the obvious. Amazon sells everything for everybody. Indirectly it's taught people they can get whatever they want online." Furthermore, internet and mobile technology have dramatically changed many industries, and team uniform sales is no exception. George described the "Amazon effect" as a purchasing phenomenon in which the average consumer now expects to be able to purchase 
anything online and have it delivered in 2-3 business days. As several participants explained, customers did not have these kind of expectations even as recently as 10 years ago. The current expectation is putting pressure on brands to develop a way to get their merchandise to consumers quickly.

Despite acknowledgment from the participants in the study that ecommerce platforms were essential in today's business, some professionals portrayed the uniform sales market as laggards when it came to adapting to an online strategy: Madeline described the industry as "relatively unsophisticated," while George expressed astonishment at the number of "pen-and-paper transactions" still taking place.

Despite these characterizations, most companies represented in this study noted online stores were an important technological advancement with significant impacts on the industry. In fact, some companies' entire business models are based on setting up online marketplaces for dealers. Ecommerce platforms offer many features, but at the simplest level, an online purchasing system replaces the traditional procedure of a team manager manually writing down her or his players' uniform sizes and numbers and then sending them to a team dealer; instead, the manager can simply enter all the information online and submit these data directly through the seller's website. Apparel brand owner Abigail is a supporter of this model of sales because it offers multiple advantages. When Abigail sets up an online team store for one of the teams she works with, it allows her to easily advertise additional products, which can increase team sales as much as " $20 \%$ "; and collect contact information directly from buyers instead of only communicating with one team representative. As a result, when her company has a promotion, she is able to reach potential consumers directly instead of relying on a team representative to spread the information or having to pay additional advertising expenses.

\section{The Future of the Market}

For a final exercise, interviewees were asked to consider what the amateur team uniform sales market will look like in the future. As expressed by a majority of respondents, the future of the industry appears to be bright; as Abigail explained, the market is "growing like crazy." According to the professionals interviewed for this study, much of this success is premised on increasingly online interaction. Four out of six interviewees highlighted using technology to sell to customers as the future of team uniform sales. Henry illustrated just how dramatically he expected the business to change:

With technology being involved, as the millennials become more involved, things are going to change a lot. Our business right now is $80 \%$ face-to-face and $20 \%$ online. In the next five years it will be reverse: $80 \%$ online and $20 \%$ face-to-face, if that. 
Three other interviewees explicitly stated either mobile or ecommerce platforms were the most important technological advancements that would be made.

For those who resisted the movement toward online transactions, the future would be filled with less optimism, based on the testimony of several industry leaders. As Felix explained,

I think they're in real danger of being pushed out and dying, and dying pretty quickly. ...I'm sure that as people look at opportunities in this space there will probably be more consolidation and some smaller companies will struggle to compete, and unless you built a really good mousetrap, it is going to be difficult.

George offered a similar analysis by using an analogy of Amazon and Walmart:

Amazon will continue to kill Walmart because Walmart thinks they're a retail location first. Amazon? What they did when they started out the company [was] said, "No, we're a know-everything-about-the-customer first, and we will reverse-engineer the metrics and logistics of getting any product you want because I know you better than anybody."

Thus, the companies that focus on customer acquisition may be better positioned for long-term success. For smaller companies that avoid acquisition from larger conglomerates, their ability to maintain competition in a crowded marketplace will be difficult. For George, the most viable companies will be the ones who can work through the increasingly complex challenges that come with large, dynamic inventories and high-volume sales:

[The business has] very complicated logistics, especially technology centered, with the production of an item and the delivery to the individual consumer, and [the company that is] able to understand their consumer better than anybody else-they'll be the one to win.

In summary, the future of the industry is heavily influenced by a rise in ecommerce and the ability for consumers to purchase any product without having to coordinate a meeting or sales call with a company representative. The next generation of buyers and sellers in the team uniform sales market is notably more comfortable with the use of mobile technology to facilitate transactions. The use of technology will also allow consumers to more easily shop for the best available deals, putting pressure on brands to offer high quality products and the lowest possible prices. Brands will have to find new ways of differentiating their products and getting in front of an increasingly technologically savvy audience, while dealers themselves will have to find a way to remain relevant in the rapidly evolving business structure.

\section{Concluding Remarks}

There are practical implications for businesses in the amateur team uniform 
sales market that can be gleaned from this study. First, all industry competitors should consider placing significant resources into developing effective methods for interacting with customers online and through mobile technology. This imperative is especially applicable for team dealers, as larger brand companies (e.g., Nike, Adidas, Under Armour) may be using their vast resources to try and cut dealers out of the equation. If the brands are able to sell to teams directly-which is becoming ever more viable with the use of modern mobile technology-there is essentially no purpose for the team dealer in their current capacity. As Felix suggested, there will always be a need for on-the-ground personnel to deliver or fix orders and interact with teams face-to-face. However, once brands are able to sell directly to teams, a team dealer may essentially function as a customer service representative for the larger brand and not as an independent dealer.

For companies looking to expand operations to the ecommerce side, a number of network partners provide online educational resources. Team Uniform Orders, or TUO, has a multitude of resources for companies looking to start or grow their online presence. The ecommerce company, whose mission is to "fix the chaos too often associated with ordering sports gear and uniforms for teams" (Team Uniform Orders, 2018), states one of the keys to future sales is establishing a central customer contact database and creating a unified customer experience through multiple online shopping experiences for increased sales per customer. In addition, through online ordering, customers can receive an email receipt that also allows for printed discounts or offers. An integral piece of returning customers is email marketing, which is utilized through the customer contact database. TUO makes note that today people check their email three times more often throughout the day than they are on social media: "Email marketing can be tracked and analyzed in great detail. ...It is one of the most affordable means for staying in 'constant contact' with your customers" (Team Uniform Orders, 2017a, p. 6). Resources on the website even touch on the importance of collecting and then protecting data from other buying groups or vendors.

TUO also points out several trends in online ordering (Team Uniform Orders, 2017b). First, because of the so-called Amazon effect, customers demand experiences comparable with online retailers, including fast service, ease of use, and fast delivery. Direct-to-team ordering is another important aspect, which reduces the likelihood of a company's clients being stolen from upstart competitors. Of course, online ordering platforms are a necessity, especially given TUO's prediction that by 2020 , over $75 \%$ of team uniform transactions will take place online. Furthermore, top brands like Nike and Adidas will choose to consolidate only with top performers. Finally, there are new standards set by consumers, and salespersons must work to meet custom- 
er experience expectations. Perhaps the most important recommendation TUO offers is directed at organizations looking to develop an online presence: it should not be done without the aid of an individual or firm that specializes in building and managing ecommerce platforms.

Collectively, the testimony collected in this study indicates the amateur team uniform sales industry is rapidly changing, and that the large number of independent dealers and the rise of consolidation has led to a more crowded and competitive marketplace. It appears that the existence of small-town, independent shops will become increasingly rare, and that unless they venture into online sales to cater to the changing demographics of consumers, they risk falling behind.

This study represents an exploratory effort to understand trends and challenges in the amateur team uniform sales market. We acknowledge several research limitations and encourage other scholars to consider these limitations before building on this study. First, while interviews consisted of two team dealers, three brand representatives, and one software development manager, follow-up studies may include the insight of other role players, including consumers. Second, as may be expected when reporting empirical material collected from interviews, some interview characteristics may not necessarily be reflected in the transcript (e.g., tone, volume, hesitations). A strength of this study is the knowledge of those with whom we interviewed; still, given the lack of sales figures and broader data on the industry, it is difficult to quantify the exact degree to which the market factors identified in this study are significant. In future studies, researchers may consider adding a quantitative assessment to gain a more detailed sense of the relative impact of some of the market changes interviewees were describing. Enhancements made in response to the above limitations would help create a clearer overall picture of the amateur team uniform sales market.

\section{References}

Aspen Institute. (2017). State of play 2017: Trends and developments. Retrieved from https://assets.aspeninstitute. org/content/uploads/2017/12/FINAL-SOP2017-report.pdf Attrill, M. J., Gresty, K. A., Hill, R. A., \& Barton, R. A. (2008). Red shirt colour is associated with long-term team success in English football. Journal of Sports Sciences, 26, 577-582. doi:10.1080/02640410701736244 Baumann-Pauly, D., Scherer, A. G., \& Palazzo, G. (2016). Managing institutional complexity: A longitudinal study of legitimacy strategies at a sportswear brand company. Journal of Business Ethics, 137, 31-51. doi:10.1007/s10551-014-2532-x Bouchet, A., Doellman, T. W., Troilo, M., \& Walkup, B. R. (2017). Pre-empting the competition: How do shareholders view sponsorships in the sport apparel industry? Journal of Sport Management, 31, 275-287. doi:10.1123/ jsm.2016-0151 
BSN Sports. (2018). About BSN

Sports. Retrieved from http://www. bsnsports.com/aboutus

Cheng, A. (2018, June 1). Take note, Nike and Adidas: Lululemon may become a real threat. Forbes. Retrieved from https://www.forbes.com/sites/ andriacheng/2018/06/01/take-notenike-adidas-lululemon-may-becomea-real-threat/\#447956eb6d8f

Craik, J. (in press). Athleisure: On the materiality and transgression of sports uniforms. In H. Jenss \& V. Hofmann (Eds.), Fashion and materiality: Cultural practices in global contexts. London: Bloomsbury Visual Arts.

Delgado, F. J. (2012). High school uniforms are traditional ... all-star uniforms are flashy ... the older the group the more "edgy" the uniform. Team Business, 4(2), 28-29.

Desbordes, M. (2002). Empirical analysis of the innovation phenomenon in the sports equipment industry. Technology Analysis \& Strategic Management, 14, 481-498. doi:10.1080/0953732022000028764

IBISWorld. (2018). Costume \& team uniform manufacturing in the US industry market research report. Retrieved from http://www.ibisworld.com

Ko, E., Taylor, C. R., Sung, H., Lee, J., Wagner, U., Navarro, D. M.-C., \& Wang, F. (2012). Global marketing segmentation usefulness in the sportswear industry. Journal of Business Research, 65, 1565-1575. doi:10.1016/j. jbusres.2011.02.041e
Krippendorff, K. (2018). Content analysis: An introduction to its methodology (4th ed.). Thousand Oaks, CA: SAGE Publications, Inc.

Lee, D. (Director). (2016). Friedman's shoes [Television series episode]. 30 for 30 shorts. Retrieved from http:// www.espn.com $/ 30$ for $30 /$ film?page $=$ friedmansshoes

Mays, J., \& Bass, J. (2016, June). Dressed to the nines: Using fashion theory to explain athlete apparel choice. Poster session presented at the meeting of the North American Society for Sport Management, Orlando, FL.

National Federation of State High School Associations. (2018). 2017-18 high school athletics participation survey. Retrieved from https://www.nfhs. org/ParticipationStatistics/ParticipationStatistics/

O'Sullivan, G. A., Hanlon, C., Spaaij, R., \& Westerbeek, H. (2017). Women's activewear trends and drivers: A systematic review. Journal of Fashion Marketing and Management, 21, 2-15. doi:10.1108/JFMM-07-2015-0059

Pallerino, M. J. (2009). Not your father's varsity jacket market. Team Business, 1(4), 52-55.

Rouziès, D., Anderson, E., Kohli, A. K., Michaels, R. E., Weitz, B. A., \& Zoltners, A. A. (2005). Sales and marketing integration: A proposed framework. Journal of Personal Selling and Sales Management, 25, 113-122. doi:10. 1080/08853134.2005.10749053

Scheerder, J., Vos, S., \& Taks, M. (2011). Expenditures on sport apparel: Cre- 
ating consumer profiles through interval regression modelling. European Sport Management Quarterly, 11, 251-274. doi:10.1080/16184742.2011 .577931

Scola, Z., \& Gordon, B. S. (2018). A conceptual framework for retro marketing in sport. Sport Marketing Quarterly, 27, 197-210.

Spencer, J. L. (2017). An examination and evaluation of uniform color across North American professional team sports. Journal of Sport Behavior, 40, 399-409.

Sports and Fitness Industry Association (2015, April 20). Sports and fitness industry surpasses $\$ 84$ billion in wholesale sales [Press release]. Retrieved from https://www.sfia.org/press/706_ Sports-and-Fitness-Industry-Surpasses-\%2484-Billion-in-Wholesale-Sales

Su, J., \& Tong, X. (2015). Brand personality and brand equity: Evidence from the sportswear industry. Journal of Product \& Brand Management, 24, 124-133. doi:10.1108/JPBM-012014-0482]

Team Uniform Orders. (2017a). Remarketing: The key to ramping online sales. Retrieved from http://www.teamuniformorders.com/resources/
Team Uniform Orders. (2017b). Trends EVERY dealer/provider must know... Retrieved from http:/ /www.teamuniformorders.com/resources/

Team Uniform Orders. (2018). About us. Retrieved from http://www.teamuniformorders.com/about-us/\#ourstory

Thomson, W. C. (2009). Stretching your budget: Notes on working with sporting goods dealers. Strategies, 23(1), 20-23. doi:10.1080/08924562.2009.1 0590854

Wear, H., Heere, B., \& Clopton, A. (2016). Are they wearing their pride on their sleeve? Examining the impact of team and university identification upon brand equity. Sport Marketing Quarterly, 25, 79-89.

Wray, A. Z., \& Hodges, N. N. (2008). Response to activewear apparel advertisements by US baby boomers: An examination of cognitive versus chronological age factors. Journal of Fashion Marketing and Management, 12, 8-23. doi:10.1108/13612020810857916 